\title{
GROWTH PERFORMANCE, NUTRIENTS DIGESTIBILITY AND CARCASS MEASUREMENTS OF GROWING RABBITS FED DIETS INCORPORATED WITH LENTIL OR CHICKPEA SCREENING BY-PRODUCTS.
}

\author{
Marwa A. Suliman, Fawzia A. Hassan, Hoda El-Gabbry and Lamiaa F. Abdel-Mawla. \\ Animal Production Research Institute, Agricultural Research Center, Dokki, Giza, Egypt. \\ Corresponding author:fawzia_amer@yahoo.com
}

(Received 7/5/2019, accepted 27/6/2019)

\section{SUMMARY}

$\mathrm{T}$

This work aimed to study the influence of replacement 15 or $30 \%$ of soybean meal protein by either lentil screening by-products protein (LSBP) or chickpea screening by-products protein (CSBP) on performance, nutrients digestibility, plasma parameters, carcass measurements and economic profitability of growing rabbits. Sixty New Zealand White (NZW) growing rabbits, six weeks of age, were divided to five experimental groups. Each group included four replicates (three rabbits each) as follow: control group fed basal diet without LSBP or CSBP; the $2^{\text {nd }}, 3^{\text {th }}, 4^{\text {th }}$ and $5^{\text {th }}$ groups of rabbits fed $15 \%$ LSBP, $30 \%$ LSBP, 15\% CSBP and 30\% CSBP diets, respectively. Results showed that LSBP has lower DM, OM and EE contents than CSBP. Meanwhile, LSBP has higher CP, CF, ash\% and GE (kcal/kg) contents compared to CSBP. LSBP was higher in arginine, threonine, isoleucine, and lysine. Meantime, CSBP had higher contents in leucine, methionine and phenylalanine as predominant essential amino acids. Inclusion of LSBP and CSBP insignificantly improved FBW, BWG and FCR. However, average daily feed intake of rabbits fed $15 \%$ CSBP was higher $(\mathrm{P}<0.05)$ than those fed 30\% CSBP. No significant differences were observed in all nutrients digestibility (DM, OM, CP, EE and NFE) and nutritive values expressed as DCP\%, TDN\% and DE Kcal/kg between groups of rabbits fed LSBP and CSBP diets and those fed the control diet. Meanwhile, group of rabbits fed 30\% LSBP had higher $(\mathrm{P}<0.05)$ CP digestibility. Conversely, group of rabbits fed $30 \%$ CSBP recorded the lowest $(\mathrm{P}<0.05) \mathrm{CP}$ digestibility. Significant higher $(\mathrm{P}<0.05)$ values of plasma total protein and albumin concentrations were recorded for rabbits fed diets contained 30\% LSBP, 15 or 30\% CSBP than the control group. Moreover, there were insignificant differences in globulin and uric acid among all the experimental groups. Regarding liver functions (AST and ALT), there was a significant decrease $(\mathrm{P}<0.05)$ in AST levels with rabbits fed $30 \%$ LSBP and 15 or $30 \%$ CSBP compared to the control group. No significant differences in most carcass measurements were found between rabbits fed different levels of LSBP and CSBP diets and those fed the control diet except heart, kidneys weights and total edible parts \%. The inclusion of LSBP at a level of $15 \%$ significantly decreased $(\mathrm{P}<0.05)$ total edible parts \% compared with the inclusion of $30 \%$ CSBP and the control group. The net revenue improved by $4.16,7.75,3.43$ and $9.52 \%$ for $15 \%$ LSBP, $30 \%$ LSBP, $15 \%$ CSBP and $30 \% \mathrm{CSBP}$, respectively. The best net revenue and economical efficiency were recorded by $30 \%$ CSBP diet followed by $30 \%$ LSBP, $15 \%$ LSBP, $15 \%$ CSBP diets and the lowest one was the control group. In conclusion, lentil or chickpea screening by-products protein could be used up to $30 \%$ substitution level for soybean meal protein without any detrimental effects on performance, nutrient digestibility, plasma parameters and carcass measurements of growing rabbits.

Keywords: growing rabbits, chickpea screenings, lentil screenings, performance and digestibility, profitability.

\section{INTRODUCTION}

The use of lentil and chickpea screening by-products might reduce the costs of feed production and reduce the environmental impact. The rising prices of feed ingredients frequently used in animal feeding has led to the evaluation of alternative and less costly ingredients, as feeds which can be accounted for up to $70 \%$ of the total costs of rabbit production (Gidenne et al., 2017). Therefore, it could be argued that feed costs could be minimized by using cheaper, non-traditional feed ingredients (de Blas et al., 2018 and Uhlírová et al., 2018). The chickpea (Cicer arietinum L.) and lentil (Lens culinaris L.) are cultivated for their edible seeds, they are the major legumes in the Mediterranean Basin. Among the 17 pulses identified as food sources by FAO, the four most widely produced are common bean, chickpea, dry pea, and lentil. Pulses are concentrated sources of protein and dietary fiber and have very low-fat content (FAO, 2017).

The majority of chickpea wastes are culled chickpea (cracked, broken, fine, deformed and impurities) and chickpea processing wastes including chickpea hulls, broken and ground peas and foreign materials 


\section{Suliman et al.}

(Mousavi and Miraza Aghazadeh, 2007). Lentil screenings are the by-products of cleaning lentil seeds. They may consist of whole and broken lentils, cereal grains, weed seeds, chaff and dust. If lentils suffered from quality problems, these by-products become occasionally available to the animal feed industry (Stanford et al., 1999 and Çabuk et al. 2014). Lentil seeds are a good source of protein and energy, but low in sulphur amino acids. Amino acid supplementation is recommended when lentil seeds are used in poultry diets, therefore lentil screenings can be included up to $20 \%$ in broiler diets (Sherasia et al., 2017).

Lentil and chickpea seeds have relatively high crude protein content (24.6-30\% and 18.2-26.5\%), respectively (Feedipedia, 2016) and low digestive inhibitors (Ggrgülü, 2010). Mustafa et al. (2000) reported that chickpea and other pulse crops can be used as protein and energy source in animal diets. However, the major anti-nutritional factor in lentils is protease inhibitor, it has excessive content of polyphenols, especially tannins, but this is not present in sufficient quantities to depress animal performance (Mavromichalis, 2013).

The current study aims to investigate the effect of lentil (LSBP) and chickpea (CSBP) screening byproducts proteins substitution for soybean meal protein on growth performance, nutrients digestibility, carcass measurements and plasma parameters of growing rabbits besides, economical efficiency of experimental diets.

\section{MATERIALS AND METHODS}

The experiment was conducted at Borg El-Arab experimental station, Animal Production Research Institute (APRI), Agricultural Research Center, Egypt. The laboratories works were carried out at Laboratories of Utilization of By-Products Research Department, APRI, Giza, Egypt. The LSBP and CSBP were obtained from Egyptian holding company for silos \& storage, El Nobaria, El-Bahera governorate. Feed mixing and pelleting processes were carried out at El Nobaria manufactory, El Nobaria Station, APRI, Agricultural Research Center, Egypt.

\section{Experimental animals, diets and design}

Sixty New Zealand White (NZW) growing rabbits, 6 weeks age with live body weight ranging from 579.44 to $580.56 \mathrm{~g}$ were divided into five experimental groups, 12 rabbits in each. Five experimental diets were formulated as follow; the control diet without LSBP and CSBP, the other experimental diets were formulated by replacing two levels (15 and 30\%) of soybean meal protein by protein of LSBP and CSBP. The diets and fresh water were supplied ad libitum. The experimental period lasted for 7 weeks from 6 to 13 weeks of age. All experimental diets (Table 1) were formulated to be isonitrogenous and isocaloric, to meet all the essential nutrient requirements of growing rabbits in accordance with De Blas and Mateos (1998).

\section{Management and growth performance}

All rabbits were kept under the same management, hygienic conditions and housed in metal battery cages supplied with separated feeders. All rabbits were vaccinated against diseases and kept under veterinary control. Feed intake (FI, g/rabbit/day) and body weight gain (BWG, g/rabbit/day) were recorded weekly, accordingly, feed conversion ratio (FCR) was calculated as $\mathrm{g}$ feed / $\mathrm{g}$ gain over an experimental period.

\section{Digestion trial and chemical analyses}

Digestion trial was conducted according to Perez et al. (1995). Fifteen rabbits were used individually to digestion trial and divided to 5 groups of three per treatment. Rabbits were housed in individual metabolism cages diets for a period of 7 days (preliminary period) for adaptation then faeces were collected every 24 hours for 5 consecutive days (collection period). Samples of LSBP and CSBP, diets and feces were prepared to determine moisture, ash, crude protein, ether extract and crude fiber according to A.O.A.C. (2000). Amino acids were determined using Beckman Amino Acid Analyzer (model 6300; Beckman Coulter Inc., Fullerton, Calif., USA). Acid hydrolysis was carried out according to the method of A.O.A.C. (2012). Data of feed intake and dried feces as well as chemical analysis of feed and dried feces were used to calculate the nutrient digestion coefficients and nutritive values for each dietary treatment, as described by Fekete (1985). Digestible energy (DE, $\mathrm{Kcal} / \mathrm{Kg}$ diet) was calculated as follow: $\mathrm{DE}=\mathrm{TDN} \times 44.3$ according to Schneider and Flatt (1975).

\section{Slaughter traits}

At the end of the growing period (13 week of age), three rabbits were taken randomly from each treatment, fasted about 16 hours before slaughtering and individually weighed as pre-slaughtering weight. Animals were slaughtered according to the Islamic religion instructions with a sharp knife. The empty carcass was weighted without head and giblets. The giblets (liver, heart and kidneys) were separated and weighed. The edible giblets percentage, total edible parts and dressing percentage were calculated according to Blasco et al. (1993). 
Table (1). Ingredients and chemical composition of experimental diets.

\begin{tabular}{|c|c|c|c|c|c|}
\hline \multirow{2}{*}{ Ingredient } & \multirow[b]{2}{*}{$\begin{array}{c}\text { Control } \\
\text { diet }\end{array}$} & \multicolumn{4}{|c|}{$\begin{array}{l}\text { Substitution level of legumes screenings by-products } \\
\text { protein }\end{array}$} \\
\hline & & $\begin{array}{c}15 \% \\
\text { LSBP }\end{array}$ & $\begin{array}{l}30 \% \\
\text { LSBP }\end{array}$ & $\begin{array}{c}15 \% \\
\text { CSBP }\end{array}$ & $\begin{array}{l}30 \% \\
\text { CSBP }\end{array}$ \\
\hline Soybean meal (44\% CP) & 20.0 & 17.00 & 14.00 & 17.00 & 14.00 \\
\hline Legume screenings by-products & 0.00 & 5.44 & 10.86 & 5.90 & 11.77 \\
\hline Yellow corn & 12.80 & 12.80 & 12.80 & 12.80 & 12.60 \\
\hline Barley & 15.00 & 15.00 & 15.00 & 15.00 & 15.00 \\
\hline Wheat bran & 12.15 & 12.15 & 12.15 & 12.15 & 12.15 \\
\hline Clover hay & 34.00 & 31.56 & 29.14 & 31.10 & 28.43 \\
\hline DL-methionine & 0.20 & 0.20 & 0.20 & 0.20 & 0.20 \\
\hline Di calcium phosphate & 2.00 & 2.00 & 2.00 & 2.00 & 2.00 \\
\hline Sodium chloride $(\mathrm{NaCl})$ & 0.35 & 0.35 & 0.35 & 0.35 & 0.35 \\
\hline Vitamin and mineral primix ${ }^{1}$ & 0.30 & 0.30 & 0.30 & 0.30 & 0.30 \\
\hline Anti coccidia and fungi & 0.20 & 0.20 & 0.20 & 0.20 & 0.20 \\
\hline Molasses & 3.00 & 3.00 & 3.00 & 3.00 & 3.00 \\
\hline Total & 100 & 100 & 100 & 100 & 100 \\
\hline \multicolumn{6}{|l|}{ Chemical composition (DM basis) } \\
\hline $\mathrm{DM} \%$ & 82.94 & 83.00 & 83.05 & 83.06 & 83.19 \\
\hline OM\% & 94.92 & 94.94 & 94.97 & 95.06 & 95.19 \\
\hline $\mathrm{CP} \%$ & 17.48 & 17.36 & 17.05 & 17.31 & 17.03 \\
\hline $\mathrm{CF} \%$ & 13.87 & 13.60 & 13.44 & 13.27 & 13.2 \\
\hline $\mathrm{EE} \%$ & 2.01 & 2.06 & 2.11 & 2.12 & 2.23 \\
\hline NFE\% & 61.56 & 61.92 & 62.37 & 62.36 & 62.73 \\
\hline Ash\% & 5.08 & 5.06 & 5.03 & 4.94 & 4.81 \\
\hline $\mathrm{DE} \mathrm{kcal} / \mathrm{kg}^{2}$ & 2680 & 2693 & 2701 & 2708 & 2712 \\
\hline \multicolumn{6}{|c|}{ 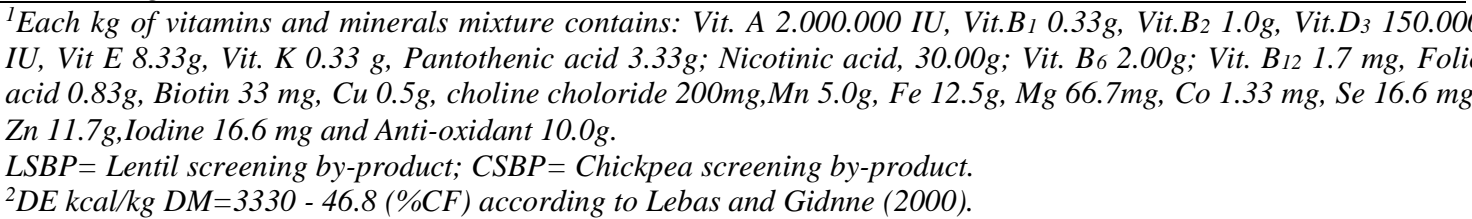 } \\
\hline
\end{tabular}

\section{Blood sampling and analysis}

Blood samples were collected during slaughter to determine blood biochemical components. Blood samples were collected at slaughtering time in heparinized glass tubes and centrifuged at 3,000 rpm for 20 minutes, then, samples were transferred and stored in deep freezer at $-20^{\circ} \mathrm{C}$ till being assayed. Plasma total protein, albumin, creatinine, uric acid, aspartate aminotransferase (AST) and alanine aminotransferase (ALT) were measured by colorimetric methods using commercial kits supplied by Bio-diagnostic, Egypt. All measurements were performed according to the manufacturer's instructions. Total protein was determined according to Gornall et al.,(1949), albumin was estimated according to Doumas and Waston, (1971), Plasma globulin concentration was calculated by the difference between total protein and albumin. Creatinine and uric acid was assayed according to Young (2001), aspartate aminotransferase (AST) and alanine aminotransferase (ALT) were determined according to Henry, (1964).

\section{Economical efficiency}

Economical efficiency was calculated as a ratio between the return of weight gain and the cost of consumed feed. The economical efficiency was calculated according to the following equation:

Economical efficiency $=($ Net revenue/ total feed cost $)$. Whereas, Net revenue $=$ Selling price/rabbit- total feed cost/rabbit. The price of ingredients and selling of one $\mathrm{kg}$ live weight of rabbits was calculated according to the price in the local market at the time of experiment during January, 2019. The price of one $\mathrm{kg}$ live body weight was 50.00 LE.

\section{Statistical analysis}

The data obtained herein were analyzed by using the GLM (General Linear Model) procedure of SAS (2004) using the following model: $Y_{i j}=\mu+T_{i}+e_{i j}$, Where, $Y_{i j}=$ An observation; $\mu=$ Overall mean; $T_{i}=$ Effect of treatment groups; $\mathrm{e}_{\mathrm{ij}}=$ experimental random error. Duncan's multiple range test (Duncan, 1955) was performed to detect significant differences between treatment means. Significance is acceptable at $(\mathrm{p} \leq 0.05)$. 


\section{Suliman et al.}

\section{RESULTS AND DISCUSSION}

\section{Chemical composition of LSBP and CSBP}

Chemical composition of LSBP and CSBP is shown in Table (2). The results indicated that LSBP had lower DM, OM and EE contents than CSBP. While, LSBP has higher CP, CF, ash\% and GE (kcal/kg) contents compared to CSBP. The chemical composition of CSBP exhibited $22.43 \% \mathrm{CP}$ content, which is close to the content of CP $(22.50 \%)$ in Kabuli chickpea type reported by Mustafa et al. (2000). Higher CP content $(23.56 \%)$ and higher fat content $(5.18 \%)$ of chickpea have been reported by Silva-Cristobal et al. (2010). Furthermore, Ladjal Ettoumi and Chibane (2015) reported that chickpea contained (24.41\%) CP and $(5.57 \%)$ crude fat. On the other hand, Maheri-Sis et al. (2007) analyzed the chemical composition of culled chickpea and chickpea dehulling by-products and found that DM, OM, CP and EE\% were 89.78, 96.90, 19.70 and 7.80\% for culled chickpea and 90.17, 92.20, 21.80 and 3.10\%, respectively for chickpea dehulling by-products. Moreover, Brenes et al. (2008) observed that chickpea contained 20\% CP, 6.4\% $\mathrm{CF}, 13.5 \% \mathrm{EE}$ and $6.4 \%$ ash. Algam et al. (2012) found that the chickpea seeds contained $24.31 \% \mathrm{CP}$, $13.37 \% \mathrm{CF}$ and $3.78 \% \mathrm{EE}$.

Concerning to the chemical composition of LSBP, Woyengo et al. (2014) found that lentil contained lower contents of DM (88.70\%), EE (1.63\%), and CF (4.10\%), and higher content of CP (27.40\%). In addition, Hefnawy (2011) stated that lentil contained $26.6 \% \mathrm{CP}, 3.40 \% \mathrm{Ash}, 1.0 \%$ fat, $6.30 \% \mathrm{CF}$ and 8.51\% moisture. Likewise, Ladjal Ettoumi and Chibane (2015) stated that lentil had higher CP content (26.34 g/100 g dry basis) and lower fat content (1.25 g/100 g dry basis). The present values of LSBP nutrients are within the range of protein (20.6-31.4\%), fat (0.7-4.3\%), carbohydrates (43.4-69.9\%) reported by Urbano et al., (2007). As demonstrated by Brummer et al. (2015), lentil is richer in total soluble fiber than peas and chickpeas. Also, like most legumes, lentil is a rich source of protein.

Table (2). Chemical composition of lentil and chickpea screenings by-products (DM basis)

\begin{tabular}{lcccccccc}
\hline Item & DM\% & OM\% & CP\% & CF\% & EE\% & Ash\% & NFE\% & GE Kcal/kg* \\
\hline LSBP & 89.20 & 93.80 & 24.30 & 12.40 & 2.20 & 6.20 & 54.90 & 4400 \\
CSBP & 90.19 & 95.69 & 22.43 & 3.04 & 3.18 & 4.31 & 67.04 & 4120 \\
\hline
\end{tabular}

${ }^{*}$ GE $(\mathrm{kcal} / \mathrm{kg})=$ Gross Energy

$L S B P=$ Lentil screening by-product; $C S B P=$ Chickpea screening by-product .

The amino acids profile of chickpea and lentil screenings by-products protein is summarized in Table (3). The present study shows that the limiting amino acids were methionine and cysteine for LSBP and CSBP. Similar results were reported by Chavan et al., (1989) who found that methionine and cysteine are the limiting amino acids in chickpeas. Pulses were very low sources of essential sulfur amino acids (Cysteine and Methionine) as mentioned by Margier et al., (2018). Besides, Lentil contains low percentages of sulphur-amino acids (Jarpa-Parra 2018). It is clear to note that LSBP had higher in contents of arginine, threonine, isoleucine and lysine while, CSBP had higher contents of leucine, methionine and phenylealanine as predominant essential amino acids.

Regarding the non-essential amino acids, LSBP had higher concentrations of alanine, aspartic acid, glutamic, glycine, proline and tyrosine. On the other hand, CSBP had higher concentration of cystine content than LSBP. The amino acids contents of LSBP and CSBP are mostly in agreement with values reported by Nestares et al. (1996); Hawthorne (2006); Lizarazo et al., (2014) and Margier et al., (2018). Therefore, lentil can be added to the range of feeds (Lizarazo et al., 2014). In general, the present results of the amino acids composition confirm that LSBP and CSBP could supply enough essential amino acids to cover the growing rabbit's nutritional requirements. High quantities of these proteins and essential amino acids in LSBP and CSBP offer an important dietary protein sources for growing rabbits.

\section{Growth performance}

Data of Table (4) revealed insignificant differences between the dietary treatments of LSBP and CSBP compared with the rabbits fed the control diet. Average daily feed intake of rabbits fed $15 \%$ CSBP was higher $(\mathrm{P}<0.05)$ than those fed 30\% CSBP. Rabbits fed the control diet recorded higher $(\mathrm{P}<0.05)$ average daily feed intake than rabbits fed $30 \%$ LSBP and those fed $30 \%$ CSBP. It is clearly to note that feed intake was linearly reduced with the increase of dietary inclusion of either LSBP or CSBP. These results were similar with the findings reported by Ciurescu et al. (2017) who demonstrated that broiler groups 
fed 20 and $40 \%$ lentil seeds replacement levels of soybean meal had an insignificant difference in DWG, FI and FCR. On the contrary, Sgğüt et al. (2018) reported that there were insignificant differences in feed intake of turkey groups fed lentil by-products up to $30 \%$ and found also that body weight gain did not affect when turkey group fed lentil by-products up to $15 \%$. While, the best of FCR was recorded by turkey group fed 25\% lentil by- products. Additionally, Hassan et al. (2016) stated that rabbits fed $25 \%$ and $50 \%$ chickpea screenings by-products achieved significantly $(\mathrm{P}<0.05)$ better average daily gain by $10.56 \%$ and $12.52 \%$, respectively and better FCR (3.65 and 3.74 vs. $4.16 \mathrm{~g}$ feed/g gain) than the control group.

Table (3). Amino acids profile of LSBP and CSBP ( $\mathrm{gkg}^{-1}$ dry matter).

\begin{tabular}{lcclcc}
\hline \multirow{2}{*}{ Item } & \multicolumn{2}{c}{ Essential amino acids } & \multicolumn{3}{c}{ Non-essential amino acids } \\
\cline { 2 - 6 } & LSBP & CSBP & & LSBP & CSBP \\
\hline Arginine & 21.3 & 18.5 & Alanine & 10.98 & 9.30 \\
Threonine & 9.90 & 8.01 & Aspartic acid & 29.0 & 22.3 \\
Histidine & 9.2 & 9.20 & Glutamic acid & 40.2 & 40.10 \\
Isoleucine & 10.60 & 9.80 & Glycine & 10.2 & 9.50 \\
Leucine & 19.01 & 21.03 & Proline & 10.5 & 9.90 \\
Lysine & 17.6 & 14.3 & Serine & 13.0 & 10.01 \\
Methionine & 2.2 & 3.40 & Cystine & 2.10 & 4.01 \\
Phenylelalanine & 12.98 & 13.87 & Tyrosine & 7.80 & 7.20 \\
Tryptophan* & - & - & & & \\
Valine & 10.98 & 14.50 & & & 123.78 \\
Total & 115.97 & 114.19 & Total & & 112.32 \\
\hline
\end{tabular}

*Not determined

$L S B P=$ Lentil screening by-product; $C S B P=$ Chickpea screening by-product.

Table (4). Growth performance of growing rabbits fed on experimental diets

\begin{tabular}{|c|c|c|c|c|c|c|}
\hline \multirow[b]{2}{*}{ Item } & \multicolumn{6}{|c|}{ Substitution level of legume screenings by-products protein } \\
\hline & Control & $15 \%$ LSBP & $30 \%$ LSBP & $15 \% \mathrm{CSBP}$ & $30 \% \mathrm{CSBP}$ & $P$-value \\
\hline \multirow{2}{*}{$\begin{array}{l}\text { Initial live body } \\
\text { weight, (IBW)(g) }\end{array}$} & 580.56 & 580.56 & 579.44 & 580.56 & 580.56 & \multirow{2}{*}{1.00} \\
\hline & \pm 26.88 & \pm 24.43 & \pm 26.23 & \pm 24.88 & \pm 23.46 & \\
\hline \multirow{2}{*}{$\begin{array}{l}\text { Final live body } \\
\text { weight, }(\text { FBW })(g)\end{array}$} & 2011.67 & 2013.89 & 2016.67 & 2013.33 & 2015.56 & \multirow{2}{*}{1.00} \\
\hline & \pm 70.98 & \pm 50.91 & \pm 47.28 & \pm 45.13 & \pm 34.93 & \\
\hline \multirow{2}{*}{$\begin{array}{l}\text { Daily weight gain } \\
\text { (DWG) (g/rabbit/day) }\end{array}$} & 29.21 & 29.25 & 29.33 & 29.24 & 29.28 & \multirow{2}{*}{1.00} \\
\hline & \pm 1.48 & \pm 1.09 & \pm 1.25 & \pm 1.12 & \pm 0.65 & \\
\hline \multirow{2}{*}{$\begin{array}{l}\text { Average daily feed } \\
\text { intake (ADFI) } \\
\text { (g/rabbit/day) }\end{array}$} & $113.20^{\mathrm{a}}$ & $108.07^{\mathrm{abc}}$ & $106.46^{\mathrm{bc}}$ & $109.44^{\mathrm{ab}}$ & $102.94^{\mathrm{c}}$ & \multirow{2}{*}{0.003} \\
\hline & \pm 1.83 & \pm 2.42 & \pm 1.88 & \pm 0.96 & \pm 1.02 & \\
\hline \multirow{2}{*}{ FCR (g feed/g gain) } & 3.87 & 3.69 & 3.63 & 3.74 & 3.52 & \multirow{2}{*}{0.44} \\
\hline & \pm 0.22 & \pm 0.13 & \pm 0.19 & \pm 0.14 & \pm 0.08 & \\
\hline
\end{tabular}

$a, b$ and $c$ means within the same row with common letter are not significantly different $(p>0.05)$.

In the present study, although rabbits did not have a significant improvement in growth performance, no deterioration in growth performance was observed during the growth experimental period. This may be due to that lentil and chickpeas screening by-products are rich sources of energy and protein and also could supply enough essential amino acids as presented in Tables ( 2 and 3 ) to cover the growing rabbit's nutritional requirements. Additionally, chickpeas and lentils are low in anti-nutritional factors. However, trypsin inhibitor limits the inclusion of chickpeas at high levels and excessive amounts may cause 
digestive problems (Hawthorne, 2006). In this respect, Hassan et al. (2016) mentioned that the chickpea screenings by-products seem to be satisfactory an energy source for the weaned rabbit and it could be used at 25 and $50 \%$ in replacement of barley as a non-conventional feedstuff without any detrimental effects on the growth performance. In the same concern, lentil screenings had tannin concentrations of $1.4 \%$ (expressed as catechin equivalents) (Stanford et al. 1999), but this is not present in sufficient quantities to depress animal performance (Mavromichalis, 2013). Furthermore, Chickpea screenings byproducts contained $4.57 \mathrm{~g} / 100 \mathrm{~g}$ DM phytic acid; $0.90 \mathrm{~g} / \mathrm{kg}$ saponins and $1.44 \mathrm{~g} / \mathrm{kg}$ tannins (Hassan et al., 2016), so there are some constraints to the inclusion levels of chickpea and lentil screenings by-products in rabbit diets. It is worth to note that bioactive compounds like polyphenol and high nutritional compositions of chickpea and lentil screening by-products are highly associated with improving the rabbit's health. Therefore, chickpeas and lentils screenings by-products are useful as protein and energy sources for rabbits diets.

\section{Nutrients digestibility and nutritive values}

Nutrients digestibility and nutritive values of rabbits fed experimental diets are summarized in Table (5). The results indicated that no significant changes were noticed in all nutrients digestibility of DM, $\mathrm{OM}, \mathrm{CP}, \mathrm{CF}, \mathrm{EE}$ and NFE between groups of rabbits fed LSBP and CSBP diets and those fed the control diet. Meanwhile, a group of rabbits fed 30\% LSBP had the highest $(\mathrm{P}<0.05)$ of CP digestibility. Conversely, a group of rabbits fed $30 \%$ CSBP recorded the lowest $(\mathrm{P}<0.05) \mathrm{CP}$ digestibility. In regard to

Table (5). Nutrients digestibility and nutritive values of growing rabbits fed on different levels of LSBP and CSBP.

\begin{tabular}{|c|c|c|c|c|c|c|}
\hline \multirow[b]{2}{*}{ Item } & \multicolumn{6}{|c|}{$\begin{array}{l}\text { Substitution level of legume screenings by- } \\
\text { products protein }\end{array}$} \\
\hline & $\begin{array}{c}\text { Control } \\
\text { diet }\end{array}$ & $\begin{array}{l}15 \% \\
\text { LSBP }\end{array}$ & $\begin{array}{l}30 \% \\
\text { LSBP }\end{array}$ & $\begin{array}{l}15 \% \\
\text { CSBP }\end{array}$ & $\begin{array}{c}30 \% \\
\text { CSBP }\end{array}$ & $P$-value \\
\hline \multicolumn{7}{|l|}{ Nutrient digestibility (\%) } \\
\hline Dry matter (DM) & $\begin{array}{l}84.86 \\
\pm 3.57\end{array}$ & $\begin{array}{l}78.63 \\
\pm 3.53\end{array}$ & $\begin{array}{l}81.34 \\
\pm 2.85\end{array}$ & $\begin{array}{l}77.07 \\
\pm 1.52\end{array}$ & $\begin{array}{l}81.76 \\
\pm 3.59\end{array}$ & 0.48 \\
\hline Organic matter (OM) & $\begin{array}{l}86.27 \\
\pm 3.12\end{array}$ & $\begin{array}{l}80.49 \\
\pm 3.09\end{array}$ & $\begin{array}{l}82.85 \\
\pm 2.82\end{array}$ & $\begin{array}{l}78.98 \\
\pm 1.34\end{array}$ & $\begin{array}{l}83.64 \\
\pm 3.08\end{array}$ & 0.43 \\
\hline Crude protein $(\mathrm{CP})$ & $\begin{array}{c}86.08^{a b c} \\
\pm 0.54\end{array}$ & $\begin{array}{c}86.53^{\mathrm{ab}} \\
\pm 1.16\end{array}$ & $\begin{array}{l}88.22^{\mathrm{a}} \\
\pm 0.94\end{array}$ & $\begin{array}{c}84.52^{\mathrm{bc}} \\
\pm 0.09\end{array}$ & $\begin{array}{l}83.67^{\mathrm{c}} \\
\pm 0.91\end{array}$ & 0.02 \\
\hline Crude fiber $(\mathrm{CF})$ & $\begin{array}{l}45.71 \\
\pm 4.23\end{array}$ & $\begin{array}{l}42.18 \\
\pm 3.84\end{array}$ & $\begin{array}{l}38.40 \\
\pm 5.82\end{array}$ & $\begin{array}{l}26.81 \\
\pm 2.03\end{array}$ & $\begin{array}{l}33.11 \\
\pm 5.83\end{array}$ & 0.09 \\
\hline Ether extract (EE) & $\begin{array}{l}77.61 \\
\pm 1.17\end{array}$ & $\begin{array}{r}73.29 \\
\pm 2.08\end{array}$ & $\begin{array}{r}72.05 \\
\pm 6.28\end{array}$ & $\begin{array}{l}70.44 \\
\pm 5.66\end{array}$ & $\begin{array}{l}81.78 \\
\pm 1.09\end{array}$ & 0.31 \\
\hline Nitrogen free extract (NFE) & $\begin{array}{l}88.95 \\
\pm 2.60\end{array}$ & $\begin{array}{l}82.63 \\
\pm 3.62\end{array}$ & $\begin{array}{l}85.75 \\
\pm 1.73\end{array}$ & $\begin{array}{l}83.80 \\
\pm 0.98\end{array}$ & $\begin{array}{l}87.15 \\
\pm 2.39\end{array}$ & 0.41 \\
\hline Nutritive value & & & & & & \\
\hline $\begin{array}{l}\text { Digestible crude protein } \\
\text { (DCP\%) }\end{array}$ & $\begin{array}{l}15.42^{\mathrm{ab}} \\
\pm 0.10\end{array}$ & $\begin{array}{l}15.41^{\mathrm{ab}} \\
\pm 0.22\end{array}$ & $\begin{array}{l}15.64^{\mathrm{a}} \\
\pm 0.18\end{array}$ & $\begin{array}{l}15.00^{\mathrm{b}} \\
\pm 0.02\end{array}$ & $\begin{array}{l}14.95^{\mathrm{b}} \\
\pm 0.17\end{array}$ & 0.04 \\
\hline $\begin{array}{l}\text { Total digestible of nutrients } \\
\text { (TDN\%) }\end{array}$ & $\begin{array}{l}77.88 \\
\pm 2.58\end{array}$ & $\begin{array}{l}73.16 \\
\pm 2.88\end{array}$ & $\begin{array}{l}74.07 \\
\pm 2.30\end{array}$ & $\begin{array}{l}71.02 \\
\pm 1.18\end{array}$ & $\begin{array}{l}74.17 \\
\pm 2.52\end{array}$ & 0.41 \\
\hline $\begin{array}{l}\text { Digestible energy (DE } \\
\text { Kcal/kg) }\end{array}$ & $\begin{array}{l}3450.10 \\
\pm 114.58\end{array}$ & $\begin{array}{l}3240.80 \\
\pm 127.83\end{array}$ & $\begin{array}{l}3281.20 \\
\pm 102.08\end{array}$ & $\begin{array}{l}3146.30 \\
\pm 52.45\end{array}$ & $\begin{array}{l}3285.90 \\
\pm 111.45\end{array}$ & 0.41 \\
\hline
\end{tabular}

nutritive values expressed as $\mathrm{DCP} \%$, TDN\% and DE Kcal $/ \mathrm{kg}$. Data showed significant $(\mathrm{P}<0.05)$ differences in DCP\% between the group of rabbits fed 30\% LSBP and groups of rabbits fed 15 or $30 \%$ CSBP. However, it is clearly noticed insignificant differences in DCP\%, TDN\% and DE Kcal $/ \mathrm{kg}$ among the control group and the other tested groups. On the contrary, Hassan et al., (2016) demonstrated that rabbits group fed 25 or $50 \%$ chickpea screenings by-products recorded significantly $(\mathrm{P}<0.05)$ higher digestibilities of DM, OM, CP, CF, EE and NFE compared with the other tested levels of 0,75 and $100 \%$ chickpea screenings by-products. As well the digestibility and biological value of chickpea nutrients are high for poultry (Brenes et al., 2008 and Nalle, 2009). However, due to the presence of anti-nutritional factors, it could have contributed to decrease nutrients digestibility of DM, OM, CF, EE and NFE. Besides, Stanford et al. (1999) found that lentil screenings have poor OM digestibility. Furthermore, 
chickpea contains a number of secondary compounds that can impair nutrient absorption from the gastrointestinal tract such as variable amounts of trypsin and chymotrypsin inhibitors that may decrease the feeding value for poultry (Bampidis and Christodoulou, 2011). At the same time, Johnson et al., (2013) stated that lentils are known to be a good source of prebiotics and have nutritionally important quantities of prebiotic carbohydrates (12.3-14.1 g/100 g of dry lentils) that help to keep up the gut microbial environment and prevent gut-associated diseases. So, those prebiotic carbohydrates promote the growth of beneficial bacteria in the gut. Lentil and chickpea are rich in prebiotic carbohydrates (Siva et al., 2019). This could explain the significant increase in CP digestibility for a group of rabbits fed 30\% LSBP compared to those fed 15 or $30 \%$ CSBP because LSBP promotes gut motility and increasing retention in the gut of rabbits.

\section{Blood plasma parameters}

Results of Table (6) illustrated significant higher $(\mathrm{P}<0.05)$ values of plasma total protein and albumin concentrations for rabbits fed diets contained $30 \%$ LSBP and 15 or $30 \%$ CSBP than the control group. While, no significant differences in plasma total protein and albumin values were observed between the rabbits fed 15\% LSBP and those fed the control diet. Moreover, the inclusion of LSBP and CSBP did not significantly affect globulin and uric acid among all the experimental groups. Regarding liver functions (AST and ALT), there were significant decreases $(\mathrm{P}<0.05)$ in AST levels with rabbits fed $30 \%$ LSBP and 15 or $30 \%$ CSBP compared with a those fed $15 \%$ LSBP and the control group. On the other hand, the inclusion of LSBP and CSBP at tested levels of 15 and $30 \%$ decreased $(\mathrm{P}<0.05)$ the blood plasma ALT levels. Rabbits fed the control diet recorded the highest $(\mathrm{P}<0.05)$ ALT level compared with the other groups. In regard to kidneys function, rabbits fed diets included 30\% LSBP and 15 or $30 \%$ CSBP had a significant decrease $(\mathrm{P}<0.05)$ in creatinine levels compared with $15 \%$ LSBP and the control group.

Table (6). Plasma parameters of growing rabbits fed on different levels of LSBP and CSBP.

\begin{tabular}{|c|c|c|c|c|c|c|}
\hline \multirow[b]{2}{*}{ Item } & \multicolumn{4}{|c|}{$\begin{array}{r}\text { Substitution level of legume screenings } \\
\text { protein }\end{array}$} & \multicolumn{2}{|c|}{ by-products } \\
\hline & $\begin{array}{c}\text { Control } \\
\text { diet }\end{array}$ & $15 \% \mathrm{LSBP}$ & $30 \%$ LSBP & $15 \% \mathrm{CSBP}$ & $30 \% \mathrm{CSBP}$ & $P$-value \\
\hline \multicolumn{7}{|l|}{ Plasma proteins } \\
\hline $\begin{array}{l}\text { Total Protein } \\
(\mathrm{mg} / \mathrm{dl})\end{array}$ & $\begin{array}{l}6.79^{\mathrm{b}} \\
\pm 0.49\end{array}$ & $\begin{array}{l}7.05^{\mathrm{ab}} \\
\pm 0.13\end{array}$ & $\begin{array}{r}7.92^{\mathrm{a}} \\
\pm 0.06\end{array}$ & $\begin{array}{r}7.81^{\mathrm{a}} \\
\pm 0.23\end{array}$ & $\begin{array}{r}7.88^{\mathrm{a}} \\
\pm 0.15\end{array}$ & 0.03 \\
\hline Albumin (mg/dl) & $\begin{array}{l}3.87^{\mathrm{c}} \\
\pm 0.03\end{array}$ & $\begin{array}{l}4.06^{\mathrm{c}} \\
\pm 0.13\end{array}$ & $\begin{array}{l}4.63^{b} \\
\pm 0.13\end{array}$ & $\begin{array}{l}4.88^{\mathrm{ab}} \\
\pm 0.09\end{array}$ & $\begin{array}{r}4.98^{\mathrm{a}} \\
\pm 0.08\end{array}$ & $<.0001$ \\
\hline Globulin (mg/dl) & $\begin{array}{c}2.92 \\
\pm 0.49\end{array}$ & $\begin{array}{c}2.99 \\
\pm 0.17\end{array}$ & $\begin{array}{c}3.29 \\
\pm 0.07\end{array}$ & $\begin{array}{c}2.93 \\
\pm 0.14\end{array}$ & $\begin{array}{c}2.90 \\
\pm 0.12\end{array}$ & 0.79 \\
\hline \multicolumn{7}{|l|}{ Liver functions } \\
\hline AST (U/ml) & $\begin{array}{l}45.27^{\mathrm{a}} \\
\pm 1.03\end{array}$ & $\begin{array}{l}43.04^{\mathrm{a}} \\
\pm 0.89\end{array}$ & $\begin{array}{l}38.62^{\mathrm{b}} \\
\pm 1.14\end{array}$ & $\begin{array}{l}37.33^{\mathrm{b}} \\
\pm 0.77\end{array}$ & $\begin{array}{l}32.05^{\mathrm{c}} \\
\pm 1.21\end{array}$ & $<.0001$ \\
\hline ALT(U/ml) & $\begin{array}{l}40.28^{\mathrm{a}} \\
\pm 0.92\end{array}$ & $\begin{array}{l}36.61^{\mathrm{b}} \\
\pm 0.42\end{array}$ & $\begin{array}{l}35.39^{\mathrm{b}} \\
\pm 1.16\end{array}$ & $\begin{array}{l}31.17^{\mathrm{c}} \\
\pm 1.01\end{array}$ & $\begin{array}{l}24.58^{\mathrm{d}} \\
\pm 1.64\end{array}$ & $<.0001$ \\
\hline \multicolumn{7}{|l|}{ Kidneys functions } \\
\hline Creatinine (mg/dl) & $\begin{array}{l}1.18^{\mathrm{a}} \\
\pm 0.02\end{array}$ & $\begin{array}{l}1.12^{\mathrm{a}} \\
\pm 0.02\end{array}$ & $\begin{array}{l}1.02^{\mathrm{b}} \\
\pm 0.03\end{array}$ & $\begin{array}{l}0.96^{\mathrm{b}} \\
\pm 0.02\end{array}$ & $\begin{array}{l}0.96^{\mathrm{b}} \\
\pm 0.02\end{array}$ & 0.0002 \\
\hline Uric acid (mg/dl) & $\begin{array}{r}3.36 \\
\pm 0.14 \\
\end{array}$ & $\begin{array}{c}4.80 \\
\pm 0.73 \\
\end{array}$ & $\begin{array}{c}6.00 \\
\pm 0.96 \\
\end{array}$ & $\begin{array}{c}5.84 \\
\pm 0.35 \\
\end{array}$ & $\begin{array}{c}6.00 \\
\pm 0.55 \\
\end{array}$ & 0.0531 \\
\hline
\end{tabular}

$a, b, c$ and $d$ means within the same row with common letter are not significantly different $(p>0.05)$.

Similar results were observed by Hassan et al. (2016) who reported insignificant differences in globulin between rabbits fed diets contained chickpea screenings by-products at levels of 25, 50, 75 and $100 \%$ of barley compared to the control group, while rabbits fed 50\% chickpea screenings by-product had higher $(\mathrm{P}<0.05)$ plasma total protein concentration than the control group. The present results disagreed with findings reported by Algam et al. (2012) who demonstrated that $10 \%$ chickpea had no significant effect on plasma total protein of broiler chicks. Also, Algam et al., (2011) found that plasma total protein did not affect in broiler fed $10 \%$ chickpea seed replaced by either groundnuts meal or sesame meal. The significant higher contents of plasma total protein and albumin for rabbits may be attributed to that LSBP and CSBP have high quality amino acids profile (Table 3). Furthermore, 
lentil protein contains all the essential amino acids however, like other legumes, it is limiting in sulphur amino acids, tryptophan and threonine (Joshi et al., 2017). Moreover, the predominant proteins in lentils are globulin (47\% of the total seed proteins) and an adequate quantity of albumin (LombardiBoccia et al. 2013). In the present study, all values of plasma constituents were within the physiological ranges according to Harcourt-Brown (2002).

\section{Carcass measurements}

The results of Table (7) revealed that insignificant differences in most carcass measurements were found between groups of rabbits fed different levels of LSBP and CSBP diets and those control diet except heart, kidneys weights and total edible parts \%. At the same time, rabbits fed 30\% CSBP were lower $(\mathrm{P}<0.05)$ in heart weight than the rabbits fed LSBP at levels of 15 or $30 \%$ and the control group. However, the rabbits fed $15 \%$ CSBP had lower $(\mathrm{P}<0.05)$ kidneys weight than those fed the control diet. The inclusion of LSBP at a level of $15 \%$ significantly decreased $(\mathrm{P}<0.05)$ total edible parts \% compared with the inclusion of $30 \% \mathrm{CSBP}$ and the control group. Similarly, Ciurescu et al. (2017) did not observe any effect on both carcass weight and dressing percentage of broiler fed two cultivars of lentil seeds up to $40 \%$ replacement of soybean meal. In contrast, Hassan et al., (2016) demonstrated significant increase $(\mathrm{P}<0.05)$ in hot carcass weight of rabbits group fed $50 \%$ chickpea screening by-products compared to the control group. They found also that $100 \%$ CSB recorded the lowest $(\mathrm{P}<0.05)$ hot carcass weight, dressing \%, Heart\% and total edible parts. The present results are in disagreement with those reported by Ndalwise (2013) who reported that hot carcass weight was decreased ( $\mathrm{P}>0.05)$ with increased levels $(32$ and $47 \%)$ of chickpea seed wastes in rabbit diets compared with the control group. The differences of carcass measurements might be due to the slaughter age, breeding, weaning age and feeding conditions (Fernandez and Fraga, 1996 and Yalçın et al., 2006).

Table (7). Carcass measurements of growing rabbits fed on the experimental diets.

\begin{tabular}{|c|c|c|c|c|c|c|}
\hline \multirow{2}{*}{ Item } & \multicolumn{6}{|c|}{$\begin{array}{l}\text { Substitution level of legume screenings } \\
\text { by-products protein }\end{array}$} \\
\hline & $\begin{array}{c}\text { Control } \\
\text { diet }\end{array}$ & $15 \%$ LSBP & $30 \%$ LSBP & $\begin{array}{c}15 \% \\
\text { CSBP } \\
\end{array}$ & $\begin{array}{c}30 \% \\
\text { CSBP } \\
\end{array}$ & $P$-value \\
\hline Pre-slaughter weight (g) & $\begin{array}{l}2110.00 \\
\pm 0.0\end{array}$ & $\begin{array}{c}2046.67 \\
\pm 77.53\end{array}$ & $\begin{array}{c}2123.33 \\
\pm 57.83\end{array}$ & $\begin{array}{l}2055.00 \\
\pm 42.52\end{array}$ & $\begin{array}{l}2108.33 \\
\pm 102.48\end{array}$ & 0.88 \\
\hline Carcass weight (g) & $\begin{array}{l}1189.61 \\
\pm 31.92\end{array}$ & $\begin{array}{c}1094.96 \\
\pm 46.67\end{array}$ & $\begin{array}{c}1187.57 \\
\pm 33.46\end{array}$ & $\begin{array}{c}1128.81 \\
\pm 29.63\end{array}$ & $\begin{array}{l}1188.25 \\
\pm 59.32\end{array}$ & 0.41 \\
\hline Dressing $(\%)$ & $\begin{array}{l}56.38 \\
\pm 1.37\end{array}$ & $\begin{array}{l}53.50 \\
\pm 0.12\end{array}$ & $\begin{array}{l}55.93 \\
\pm 1.08\end{array}$ & $\begin{array}{l}54.93 \\
\pm 0.56\end{array}$ & $\begin{array}{l}56.36 \\
\pm 0.34\end{array}$ & 0.15 \\
\hline Head (g) & $\begin{array}{l}111.667 \\
\pm 1.66\end{array}$ & $\begin{array}{l}108.333 \\
\pm 4.41\end{array}$ & $\begin{array}{l}108.333 \\
\pm 4.40\end{array}$ & $\begin{array}{l}111.667 \\
\pm 1.67\end{array}$ & $\begin{array}{l}110.00 \\
\pm 5.00\end{array}$ & 0.93 \\
\hline Liver (g) & $\begin{array}{l}80.58 \\
\pm 3.71\end{array}$ & $\begin{array}{l}73.86 \\
\pm 6.60\end{array}$ & $\begin{array}{l}80.10 \\
\pm 6.35\end{array}$ & $\begin{array}{l}85.80 \\
\pm 7.71\end{array}$ & $\begin{array}{r}73.67 \\
\pm 5.52\end{array}$ & 0.61 \\
\hline Heart (g) & $\begin{array}{l}7.33^{\mathrm{ab}} \\
\pm 0.61\end{array}$ & $\begin{array}{l}7.50^{\mathrm{ab}} \\
\pm 0.50\end{array}$ & $\begin{array}{l}8.27^{\mathrm{a}} \\
\pm 0.07\end{array}$ & $\begin{array}{l}6.40^{\mathrm{bc}} \\
\pm 0.80\end{array}$ & $\begin{array}{l}5.37^{c} \\
\pm 0.35\end{array}$ & 0.02 \\
\hline Spleen (g) & $\begin{array}{c}1.42 \\
\pm 0.27\end{array}$ & $\begin{array}{c}1.62 \\
\pm 0.32\end{array}$ & $\begin{array}{c}1.22 \\
\pm 0.40\end{array}$ & $\begin{array}{c}1.08 \\
\pm 0.25\end{array}$ & $\begin{array}{c}1.23 \\
\pm 0.12\end{array}$ & 0.72 \\
\hline Kidneys (g) & $\begin{array}{l}20.17^{\mathrm{a}} \\
\pm 1.43\end{array}$ & $\begin{array}{l}17.13^{\text {ab }} \\
\pm 0.27\end{array}$ & $\begin{array}{l}16.00^{\mathrm{ab}} \\
\pm 1.51\end{array}$ & $\begin{array}{l}15.40^{\mathrm{b}} \\
\pm 0.62\end{array}$ & $\begin{array}{c}16.07^{\mathrm{ab}} \\
\pm 1.97\end{array}$ & 0.01 \\
\hline Edible giblets $(\%)^{1}$ & $\begin{array}{c}5.12 \\
\pm 0.24\end{array}$ & $\begin{array}{c}4.83 \\
\pm 0.44\end{array}$ & $\begin{array}{c}4.90 \\
\pm 0.24\end{array}$ & $\begin{array}{c}5.23 \\
\pm 0.33\end{array}$ & $\begin{array}{c}4.53 \\
\pm 0.23\end{array}$ & 0.56 \\
\hline Total edible parts $(\%)^{2}$ & $\begin{array}{l}56.38^{\mathrm{a}} \\
\pm 1.37\end{array}$ & $\begin{array}{l}53.50^{\mathrm{b}} \\
\pm 0.12\end{array}$ & $\begin{array}{c}55.93^{\mathrm{ab}} \\
\pm 1.08\end{array}$ & $\begin{array}{c}54.93^{\mathrm{ab}} \\
\pm 0.56\end{array}$ & $\begin{array}{l}56.35^{\mathrm{a}} \\
\pm 0.34\end{array}$ & 0.01 \\
\hline Cecun length $(\mathrm{cm})$ & $\begin{array}{l}29.33 \\
\pm 0.88\end{array}$ & $\begin{array}{l}31.00 \\
\pm 1.15\end{array}$ & $\begin{array}{l}30.66 \\
\pm 0.66\end{array}$ & $\begin{array}{l}30.67 \\
\pm 1.45\end{array}$ & $\begin{array}{l}30.33 \\
\pm 0.66\end{array}$ & 0.80 \\
\hline Intestine length (cm) & $\begin{array}{l}165.00 \\
\pm 2.00 \\
\end{array}$ & $\begin{array}{r}184.00 \\
\pm 13.07 \\
\end{array}$ & $\begin{array}{r}187.66 \\
\pm 10.71 \\
\end{array}$ & $\begin{array}{r}199.66 \\
\pm 14.72 \\
\end{array}$ & $\begin{array}{r}187.67 \\
\pm 16.04 \\
\end{array}$ & 0.43 \\
\hline
\end{tabular}

$a, b$ and $c$ means within the same row with common letter are not significantly different $(p>0.05)$.

1) Edible Giblets $\%=($ liver + kidney + heart $) /$ Pre-slaughter weight $(g) * 100$

2) Total edible parts $(\%)=($ carcass $w t+$ Edible Giblets $) /$ Pre-slaughter weight $(g) * 100$ 


\section{Economical efficiency}

The present results of Table (8) show that the best economical efficiency and net revenue were recorded by $30 \%$ CSBP diet followed by 30\%LSBP, 15\%LSBP, 15\% CSBP diets and the lowest values were found for the control group. This may be related to the decreasing of total feed cost per rabbit with groups fed diets contained LSBP and CSBP because of the low prices of chickpea and lentil screenings by-products. Moreover, no impairment of growth performance was observed with groups of rabbits fed diets contained LSBP and CSBP. This is in accordance to the other results reported by Hassan et al., (2016) who stated that the inclusion of chickpea screening by-products at 25, 50, 75 and $100 \%$ in rabbit diets had an improvement in economic efficiency and net revenue compared with the control group. Therefore, lentil and chickpeas screenings by-products are useful protein sources with good quality and energy-rich feed because of their competitive price (Lardy and Anderson, 2009 and Hassan et al. 2016). It is well known that feed costs could be minimized by using cheaper and non-traditional feed ingredients. Furthermore, possible effects on animal growth performance must also be evaluated (De Blas et al., 2018 and Uhlírová et al., 2018). Effective utilization of available feed resources is the key to economical livestock rearing (Beigh et al., 2017 and Mudgal et al., 2018). So the present study confirms that LSBP and CSBP could be used as alternative protein sources with competitive prices compared with the traditional protein sources in growing rabbits.

Table (8). Economical efficiency of experimental diets included LSBP and CSBP

\begin{tabular}{lccccc}
\hline & \multicolumn{4}{c}{ Substitution level of legume screenings protein } \\
\cline { 2 - 6 } Item & $\begin{array}{c}\text { Control } \\
\text { diet }\end{array}$ & 15\%LSBP & 30\%LSBP & 15\%CSBP & 30\%CSBP \\
\hline Total body weight gain (kg) & 1.431 & 1.433 & 1.437 & 1.432 & 1.435 \\
Price of 1 kg body weight (L.E.) & 50 & 50 & 50 & 50 & 50 \\
Selling price/rabbit (L.E.) (A) & 71.56 & 71.67 & 71.86 & 71.64 & 71.75 \\
Total feed intake (kg) & 5.55 & 5.30 & 5.22 & 5.36 & 5.04 \\
Price of 1 kg feed (LE) & 4.97 & 4.88 & 4.69 & 4.88 & 4.68 \\
Total feed cost/rabbit (LE) (B) & 27.58 & 25.86 & 24.48 & 26.16 & 23.59 \\
Net revenue (LE) & 43.97 & 45.80 & 47.38 & 45.48 & 48.16 \\
Economic efficiency $^{2}$ & 1.59 & 1.77 & 1.94 & 1.74 & 2.04 \\
\hline
\end{tabular}

${ }^{I}$ Net revenue $=A-B$

${ }^{2}$ Economical efficiency $=$ Net revenue $/ B$

\section{CONCLUSION}

According to the previous results, it may be concluded that the substitution of LSBP and CSBP protein for soybean meal protein up to $30 \%$ level did not cause any adverse effects on growth performance, nutrients digestibility, plasma parameters and carcass measurements. Additionally, LSBP and CSBP diets had the best profitability. The LSBP and CSBP could be used as unconventional protein sources in growing rabbit diets.

\section{REFERENCES}

Algam, T.A.; Kh.A. Abdel Atti; B.M. Dousa; S.M. Elawad and B.A. Atta Elmanan (2011). Effect of dietary raw chickpea (cicer arietinum 1.) seeds replacement groundnut meal, sesame meal on broiler performance and blood constituents. Online Journal of Animal and Feed Research, 3(2): 91-95.

Algam, T.A.; K.A. Abdel Atti; B.M. Dousa; S.M. Elawad and A.M. Fadel Elseed (2012). Effect of dietary raw chick pea (Cicer artinum L.) seeds on broiler performance and blood constituents. International Journal of Poultry Science, 11(4):294-297.

AOAC (2000). Association of official Analytical chemists. Official Methods of Analysis, $14^{\text {th }}$ Ed. Published by the A. O. A. C. Washington, D.C., USA.

AOAC (2012). Association of Official Analytical Chemist, Official Methods of Analysis, $19^{\text {th }}$ Ed., AOAC international, Suite 500, 481 North Frederick Avenue, Gaithersburg, Maryland 20877-2417, USA. 


\section{Suliman et al.}

Bampidis, V.A. and V. Christodoulou (2011). Chickpeas (Cicer arietinum L.) in animal nutrition: A review. Animal Feed Science and Technology, 168: 1-20.

Beigh, Y.A.; A.M. Ganai and H.A. Ahmad (2017). Prospects of complete feed system in ruminant feeding: a review. Vet World, 10(4):424-437.

Blasco, A.; J. Ouhayoun and G. Masoero (1993). Harmonization of criteria and terminology in rabbit meat research. World rabbit science, 1(1):3-10.

Brenes, A.; A.Viveros; C. Centeno; I. Arija, and F. Marzo (2008). Nutritional value of raw and extruded chickpeas (Cicer arietinum L.) for growing chickens. Spanish Journal of Agricultural Research. 6(4): 537-545.

Brummer, Y.; M. Kaviani and S.M. Tosh (2015). Structural and functional characteristics of dietary fibre in beans, lentils, peas and chickpeas. Food Research International, 67, 117-125.

Çabuk, M.; S. Eratak and H.B. Malayoğlu (2014). Effects of dietary inclusion of lentil by-product on performance and oxidative stability of eggs in laying quail. Scientific World Journal, 2014:1-5. http://dx.doi.org/10.1155/2014/742987

Chavan, J. K.; S. S. Kadam and D. K. Salunkhe (1989). Chickpea. In Handbook of World Food Legumes: Nutritional Chemistry, Processing Technology, and Utilization; Salunkhe, D. K., Kadam, S. S., Eds.; CRC Press: Boca Raton, FL, Vol.I, pp 247-288.

Ciurescu, G.; A.Vasilachi; M. Habeanu and C. Dragomir (2017). Effects of dietary lentil seeds inclusion on performance, carcass characteristics and cecal $\mathrm{pH}$ of broiler chickens. Indian Journal of Animal Sciences, 87 (9): 1130-1134.

De Blas, J.C. and G.G. Mateos (1998). Feed formulation. In: De Blas, J.C., Wiseman J., (Ed). The nutrition of rabbit. Ed CABI publishing, UK. pp. 241-254.

De Blas, J.C.; P. Ferrer; C.A. Rodríguez; A. Cerisuelo; P. García-Rebollar; S. Calvet and C. Farias (2018). Nutritive value of citrus co-products in rabbit feeding. World Rabbit Sci., 26: 7-14.

Doumas, B.T. and W. Waston (1971). Albumin standards and measurement of plasma albumin with bromocresol green. Clin. Chem. Acta., 31,87.

Duncan, D. B. (1955). Multiple Range and Multiple F-Test. Biometrics, 11,1-42.

Feedipedia (2016). Animal feed resources information system. INRA/CIRAD/AFZ/FAO Available at: http://www.feedipedia.org/

Fekete, S. (1985). Rabbit feeds and feeding with special regard to tropical condition. Journal of Applied Rabbit Research, 8(4): 167-173.

Fernandez, C. and M. J. Fraga (1996). The effect of dietary fat inclusion on growth, carcass characteristics, and chemical composition of rabbits. J. Anim. Sci. 74:2088-2094.

Food and Agriculture Organization, FAO (2017). Definition and Classification of Commodities: Pulses and Derived Products. Available online: http://www.fao.org/es/faodef/fdef04e.htm (accessed on 20 January 2017).

Gidenne, T.; H. Garreau; L. Drouilhet; C. Aubert and L. Maertens (2017). Improving feed efficiency in rabbit production, a review on nutritional, technico-economical, genetic and environmental aspects. Anim. Feed Sci. Technol., 225: 109- 122.

Gorgülü, M. (2010). Ingredient of nutrients. Available from: http://www. muratgorgulu.com.tr/altekran.asp?id=79.

Gornall, A. G.; C. J. Bardawill and M. Divid (1949). Determination of plasma protein by means of the biurent reaction. J. Biol.Chem.,177, 751.

Harcourt-Brown, F. (2002). Biochemistry, in: Textbook of rabbit medicine. Oxford, UK,Elsevier, pp.148.

Hassan, F. A.; I M. R. M. brahim and M.M. Basyony (2016). Effect of chickpea screenings by-products as untraditional energy source on growth performance and digestibity of growing rabbits. Egyptian J. Nutrition and Feeds, 19 (2): 201-212.

Hawthorne, W. (2006). Pulses nutritional value and their role in the feed industry. Published by Pulse Australia Pt Wayne Hawthorne, Pulse Australia. 
Hefnawy, T.H. (2011). Effect of processing methods on nutritional composition and anti-nutritional factors in lentils (Lens culinaris). Annals of Agricultural Science, 56(2):57-61.

Henry, R.J. (1964). Clinical Chemistry, Principles and Technics. Harper row Publishers New York.

Jarpa-Parra, M. (2018). Review Lentil protein: a review of functional properties and food application. An overview of lentil protein functionality. International Journal of Food Science and Technology, 53: 892-903.

Johnson C.R.; G.F. Combs and P. Thavarajah (2013). Lentil (Lens culinaris L.): A prebiotic-rich whole food legume. Food Res. Int., 51:107-113. doi: 10.1016/j.foodres.2012.11.025.

Joshi, M.; Y. Timilsena and B. Adhikari (2017). Global production, processing and utilization of lentil: A review. Journal of Integrative Agiculture, 16(12):2898-2913.

Ladjal Ettoumi, Y. and M. Chibane (2015). Some physicochemical and functional properties of pea, chickpea and lentil whole flours. International Food Research Journal, 22(3): 987-996.

Lardy, G. and V. Anderson (2009). Alternative Feeds for Ruminants. NDSU. Extension Service, North Dakota State University Fargo, 20P.

Lebas F. and T. Gidenne (2000). Recent research advances in rabbit nutrition. Annual WRSA Chinese Branch Meeting, Ningbo (Chine) 22-23 Decembre 2000, 17 pp.

Lizarazo, C. I.; A.M. Lampi; J. Liu; T. Sontag-Strohm; V. Piironenb and F.L. Stoddard (2014). Nutritive quality and protein production from grain legumes in a boreal climate. J Sci. Food Agric. (wileyonlinelibrary.com) DOI 10.1002/jsfa.6920.

Lombardi-Boccia, G.; S. Ruggeri; A. Aguzzi and M. Cappelloni (2013). Globulins enhance in vitro iron but not zinc dialysability: A study on six legume species. J. Trace Elem. Med. Biol.,17:1-5.

Maheri-Sis, N.; M. Chamani; A.A. Sadeghi; A. Mirza-Aghazadeh and A.A. Safaei (2007). Nutritional evaluation of chickpea wastes for ruminants using in vitro gas production technique. J. Anim. Vet. Adv., 6(12): 1453-1457.

Margier , M.; S. Georgé; N. Hafnaoui; D. Remond; M. Nowicki; L.D. Chaffaut; M.J. Amiot and E. Reboul (2018). Nutritional Composition and bioactive content of legumes: Characterization of pulses frequently consumed in France and effect of the cooking method. Nutrients, 10, 1668-1680.

Mavromichalis, L. (2013). El papel de los antioxidantes en la nutrición porcina. Suis (102):6-8.

Mousavi, S. H. and A. Mira Aghaadeh (2007). Study on replacing cotton seed meal and barely by chickpea processed by-product on performance and carcass characteristics in Iranian Kizil and Makui male lambs. Proceeding of second Congress on Animal and Aquatic Sciences, Karaj, Iran, p.921-924.

Mudgal, V.; M. K. Mehta and A. S. Rane (2018). Lentil straw (Lens culinaris): An alternative and nutritious feed resource for kids. Animal Nutrition, 4: 417-421.

Mustafa, A. F.; P. A. Thacker; J.J. McKinnon; D. A. Christensen and V. J. Racz (2000). Nutritional value of feed grade chickpeas for ruminants and pigs. Journal of the Science of Food and Agriculture, 80:1581-1588.

Nalle, C.L. (2009). Nutritional evaluation of grain legumes for poultry. PhD Thesis, Massey University, Palmerston North, New Zealand.

Ndalwise, C.M. (2013). Determination of the optimal level of inclusion of chickpea (Cicer Arietinum L.) seed waste in the diets of growing rabbits. M.Sc. Thesis, sokoine university of agriculture, Morogoro, Tanzania. 144P.

Pérez, J.M.; F. Lebas; T. Gidenne; L. Mertens; G. Xiccato; R. Parigi-Bini; Z.A. Dalle; M.E. Cossu; A. Carazzolo; M.J. Villamide; R. Carabaño; M.J. Fraga; M.A. Ramos; C. Cervera; E. Blas; J. Fernandez; C.L. Falcanoe; A. Bengala and J. Freire (1995). European reference method for In vivo determination of diet digestability in rabbits. World Rabbit Science, 3(1): 41-43.

SAS; (2004). User's guide. Statistic. SAS Inst. Cary, N.C. Releigh.

Schneider, B.H. and W.P. Flatt (1975). The Evaluation of Feed Through Digestibility Experiments. University of Georgia Press Athens, Georgia, USA. 


\section{Suliman et al.}

Sharasia, P.L.; M.R. Garg and B.M. Bhanderi (2017). Pulses and their by-products as animal feed, edited by T. Calles \& H. P. S. Makkar. Rome, FAO.

Silva-Cristobal, L.; P. Osorio-Díaz; J. Tovar and L.A. Bello-Pérez (2010). Chemical composition, carbohydrate digestibility, and antioxidant capacity of cooked black bean, chickpea, and lentil Mexican varieties. CyTA - Journal of Food, 8, (1): 7-14.

Siva, N.; P. Thavarajah; S. Kumar and D. Thavarajah (2019). Variability in Prebiotic Carbohydrates in Different Market Classes of Chickpea, Common Bean, and Lentil Collected From the American Local Market. Front. Nutr. 6:38. doi: 10.3389/fnut.2019.00038.

Sgğüt, B.; F. Kurbalö; H. İnci and T. Ayaşan (2018). The Effect of Lentil-By Product on Growth Performance and Carcass Traits of Heavy White Turkeys. Brazilian Journal of Poultry Science, 20(2): 357-362.

Stanford, K.; G.L. Wallins; B.M. Lees and H.H. Mundel (1999). Use of lentil screenings in the diets of early weaned lambs and ewes in the second trimester of pregnancy. Animal Feed Science and Technology, 81(3-4): 249-264.

Nestares, T.; M. López-Frias; M. Barrionuevo and G. Urbano (1996). Nutritional Assessment of Raw and Processed Chickpea (Cicer arietinum L.) Protein in Growing Rats. J. Agric. Food Chem. 1996, 44, 2760-2765.

Uhlírová, L.; Z. Volek and M. Marounek (2018). White lupin bran and its effects on the growth performance, carcass characteristics and digestibility of nutrients in fattening rabbits. World Rabbit Sci., 26: 1-6.

Urbano, G.; J.M. Porres; J. Frias, and C. Vidal-Valverde (2007). Chapter 5 nutritional value. In: Lentil: An Ancient Crop for Modern Times. (edited by S.S. Yadav, D. McNeil \& P.C. Stevenson) Springer, Berlin, Pp. 47-93.

Woyengo, T.A.; R. Jha,; E. Beltranena; A. Pharazyn and R.T. Zijlstra (2014). Nutrient digestibility of lentil and regular- and low-oligosaccharide, micronized full-fat soybean fed to grower pigs. J. Anim. Sci. 92:229-237.

Yalçın, S.; E.E. Onbaşılar and İ. Onbaşılar (2006). Effect of Sex on Carcass and Meat Characteristics of New Zealand White Rabbits Aged 11 Weeks. Asian-Aust. J. Anim. Sci. 19,( 8) : 1212 - 1216.

Young, D.S. (2001). Effect of diseases on Clinical Lab Tests, $4^{\text {th }}$ Edition, AACC. Press, Washington, D.C.

أداء النمو وهضم العناصر الغذائيه وقياسات الذبيحة للأرانب النامية المغذاه علي علائق تحتوي علي مخلفات غربلة العدس أو الحمص.

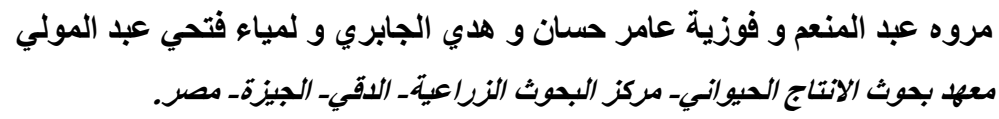

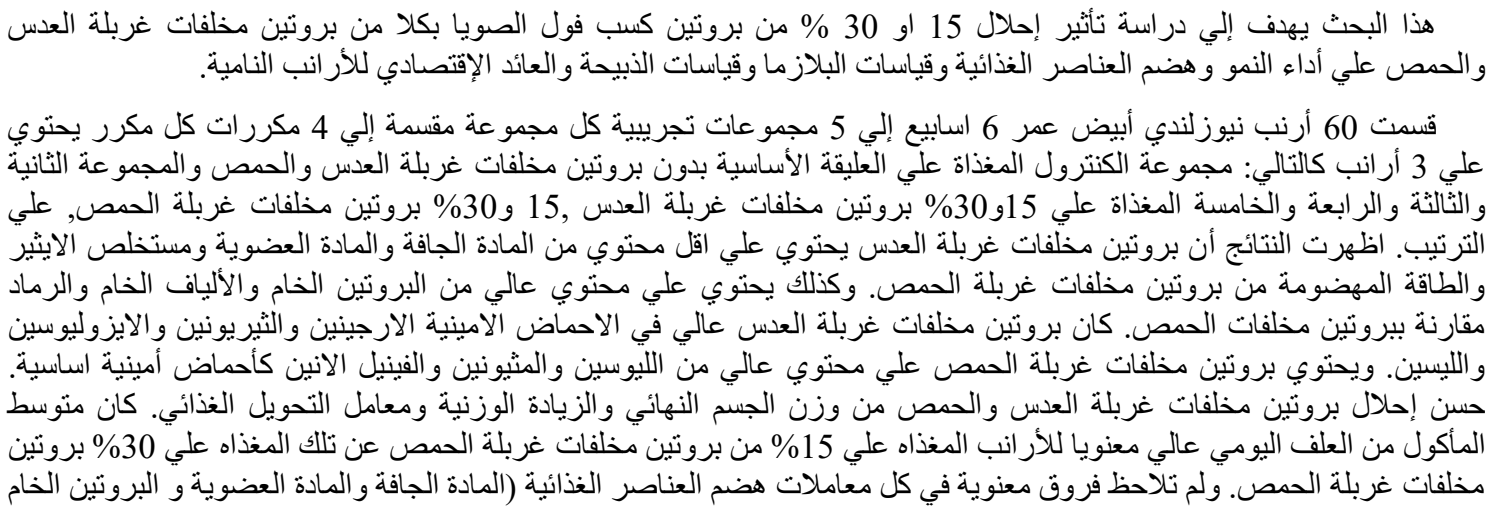


ومستخلص الإيثير والمستخلص الخالي من النيتروجين) والقيم الغذائية كالبروتين الخام المهضوم ومجموع المركبات الغذائية المهضومة

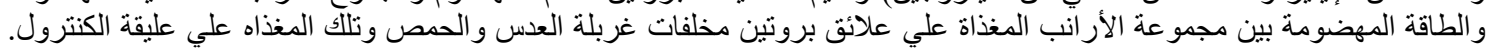

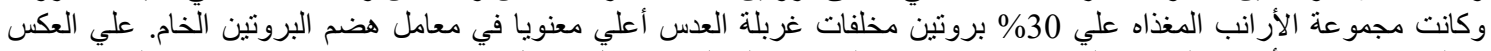

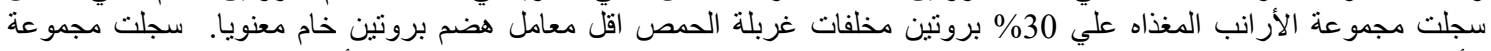

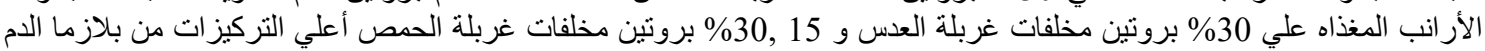

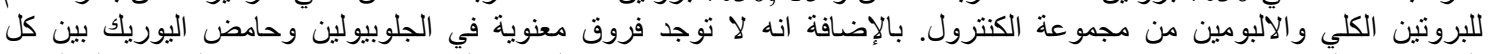

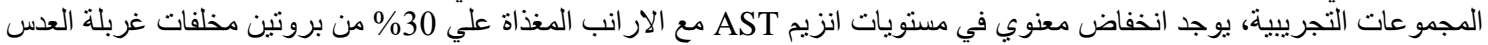

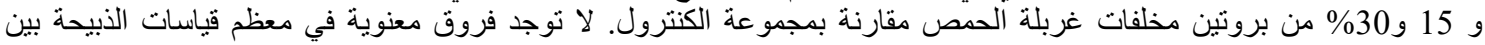

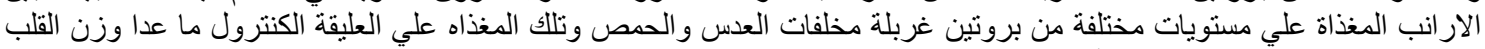

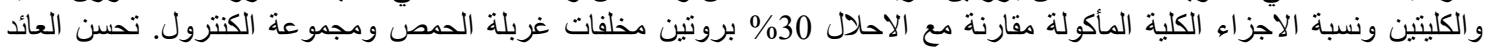

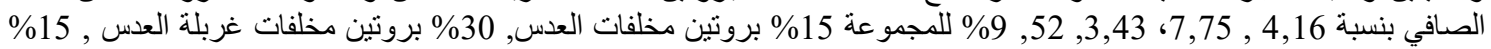

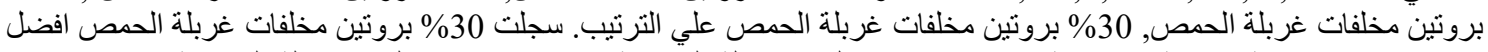

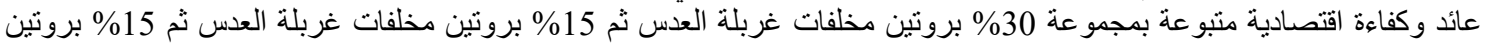

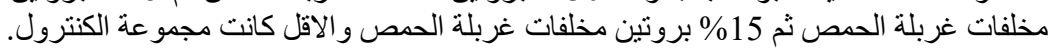

يمكن استخدام بروتين مخلفات غربلة العدس أو الحمص حتي مستوي احلال 30\% من بات بروتين كسب فول الصويا بدون اي تأثيرات سلبية علي اداء النمو ومعاملات الهضم وقين لغياسات بلازما الدم وقياستات الذبيحة للأر انب النامية. 